\title{
Penerapan Algoritma Convolutional Neural Network Dan Arsitektur MobileNet Pada Aplikasi Deteksi Penyakit Daun Padi
}

\author{
Rizal Amegia Saputra ${ }^{1}$, Sri Wasyianti ${ }^{2}$, Adi Supriyatna ${ }^{3}$, Dede Firmansyah Saefudin ${ }^{4}$ \\ 1,2,3,4Universitas Bina Sarana Informatika \\ e-mail: rizal.rga@bsi.ac.id, sri.siw@bsi.ac.id, adi.asp@bsi.ac.id, dede.dfs@bsi.ac.id
}

\begin{abstract}
Padi merupakan tanaman pangan penghasil beras, dan indonesia merupakan negera yang mayoritas penduduknya menjadikan beras sebagai makanan utama, jumlah penduduk yang semakin meningkat, perlu menjaga kualitas padi agar resiko gagal panen dapat dihindari. Banyak faktor yang dapat menimbulkan resiko gagal panen salahsatunya itu penyakit daun padi, Pada penelitian ini diusulkan Algoritma Convolutional Neural Network untuk klasifikasi penyakit daun padi yang berdasarkan citra. Arsitektur yang digunakan pada penelitian ini menggunakan MobileNetVI dengan menggunakan ekstraksi fitur. Dataset berasal dari UCI Repository sebanyak 120 yang terdiri dari 3 penyakit daun padi yaitu Bacterial leaf blight, Brown spot, Leaf smut. Berdasarkan hasil pelatihan dan pengujian menggunakan citra penyakit daun padi yang berukuran 224×224 piksel didapat hasil nilai akurasi pelatihan mencapai 1.0 dan nilai akurasi validasi mencapai 0.8333. Nilai akurasi pada Confusion Matrix yaitu sebesar 92\%, hasil ini menjadi bukti bahwa dengan penerepan algorima CNN dan MobileNetVI dengan ekstraksi ciri memiliki akurasi yang baik sekali. Percobaan pada aplikasi yang dibangun hasil proses pengujian berbasis android terbukti dapa mengklasifikasikan jenis penyakit daun padi.
\end{abstract}

Keywords: CNN, Feature Extraction, Penyakit Daun Padi

\begin{abstract}
Rice is a rice-producing food crop, and Indonesia is a country where the majority of the population makes rice as the main food, the population is increasing, it is necessary to maintain the quality of rice so that the risk of crop failure can be avoided. Many factors that can pose a risk of crop failure one of them is rice leaf disease, in this study proposed Convolutional Neural Network Algorithm for the classification of rice leaf disease based on imagery. The architecture used in this study uses MobileNetVI using feature extraction. Dataset comes from UCl Repository as many as 120 consisting of 3 rice leaf diseases namely Bacterial leaf blight, Brown spot, Leaf smut. Based on the results of training and testing using rice leaf disease imagery measuring 224x224 pixels, the results of training accuracy value reached 1.0 and validation accuracy value reached 0.8333. The accuracy value in the Confusion Matrix is $92 \%$, this result is proof that with the penetration of CNN and MobileNetVI algorithm with characteristic extraction has excellent accuracy. Experiments on applications built on the results of the android-based testing process proved to classify the type of rice leaf disease.
\end{abstract}

Keywords: CNN, Feature Extraction, Rice Leaf Disease

\section{Pendahuluan}

Sektor pertanian merupakan sektor penting bagi pertumbuhan suatu negara(Isbah \& Iyan, 2016). Pertanian padi merupakan tanaman pangan penghasil beras, dan beras salah satu komoditas utama bagi penduduk Asia dan negara tropis lainnya khususnya indonesia. Oleh karena itu aspek kualitas dan kesehatan tanaman padi menjadi hal yang paling penting untuk menjaga hasil produktivitas tanaman padi.

$$
\text { Banyak faktor yang dapat }
$$
menyebabkan gagal panen dalam produktivitas tanaman padi, salah satunya yaitu hama dan penyakit daun padi(Soleh, 2020). Sebanyak $25 \%$ gagal panen padi disebabkan oleh penyakit daun padi(Nuryanto, 2018), untuk itu perlu upaya mengurangi resiko gagal panen dengan cara mendeteksi citra daun padi secara dini(Saputra et al., 2020).

Sebagian besar penyakit daun padi disebabkan oleh patogen/parasit, penyakit daun busuk, bakteri hawar daun dan bercak coklat merupakan penyakit yang paling banyak menyerang daun padi(Pothen \& Pai, 2020) Penyakit padi yang paling umum adalah blas daun, bercak coklat, hawar 
daun(Chawathe, 2020). Proses klasifikasi dalam mendeteksi citra penyakit daun padi perlu dibangun dalam sebuah aplikasi yang menerapkan metode deep learning, agar dengan mudah para petani pemula dapat dengan cepat mengetahui jenis penyakit daun padi tersebut. Banyak metode deep learning mampu menyeleksi fitur yang komplek dan cepat namun algoritma convolutional neural network (CNN) merupakan algoritma yang paling efisien dalam mengekstraksi fitur(Rahman et al., 2020).

Penelitian terkait mengenai panyakit daun padi sudah banyak dilakukan sebelumnya, seperti penelitian (Saputra et al., 2020) klasifikasi penyakit daun padi menggunakan KNN dan ekstraksi fitur GLCM didapat akurasi $65.83 \%$ dan kappa 0.485, Penelitian (Jani \& Noor, 2018) melakukan klasifikasi penyakit daun padi dengan ekstraksi fitur GLCM dan algoritma backpropagation didapat akurasi $80 \%$. Penelitian (Phadikar \& Sil, 2008) melakukan identifikasi penyakit daun padi menggunakan algoritma zooming dalam ekstrak gambar dan algoritma neural network menghasilkan klasifikasi penyakit daun padi dengan baik. Penelitian (Phadikar, Sil, \& Das, 2013) klasifikasi penyakit daun padi dengan membandingkan dua algoritma yaitu Naive Bayes dan Support Vector Machine didapat akurasi sebesar 79,5\% dan 68.1\%, Penelitian (Minarni \& Warman, 2017) membuat aplikasi sistem pakar identifikasi penyakit daun padi menggunakan algoritma CBR menghasilkan akurasi $82,69 \%$. Penelitian (Yang et al., 2008) melakukan ekstrak fitur penyait daun padi dengan algoritma Neural Network, penelitian ini menunjukan bawah algoritma Neural Network dapat digunakan dalam klasifikasi penyakit daun padi.

Kebaharuan dalam penelitian ini akan membahas sebuah pengembangan dengan algoritma CNN dan arsitektur MobileNet dengan feature extraction dan feature map, feature map akan dapat indikasi klasifikasi beberapa penyakit daun padi yang dapat menyebabkan penurunan nilai makanan.

\section{Metode Penelitian}

Pada metode penelitian ini dilaksanakan melalui beberapa tahapan yaitu:
a. Proses Penyiapan dan Pre Proses Dataset

Pada tahap ini penyiapan dan preproses dataset dilakukan dengan mengambil gambar dari $\mathrm{UCl}$ repository https://archive.ics.uci.edu/ml/datasets/Rice +Leaf+Diseases, obyek data terdiri dari tiga macam jenis penyakit yaitu Bacterial leaf bligt, Brown Spot, Leaf Smut.

b. Desain Artitektur

Dan berikut desain arsitektur dapat dilihat pada gambar 1 dibawah ini:

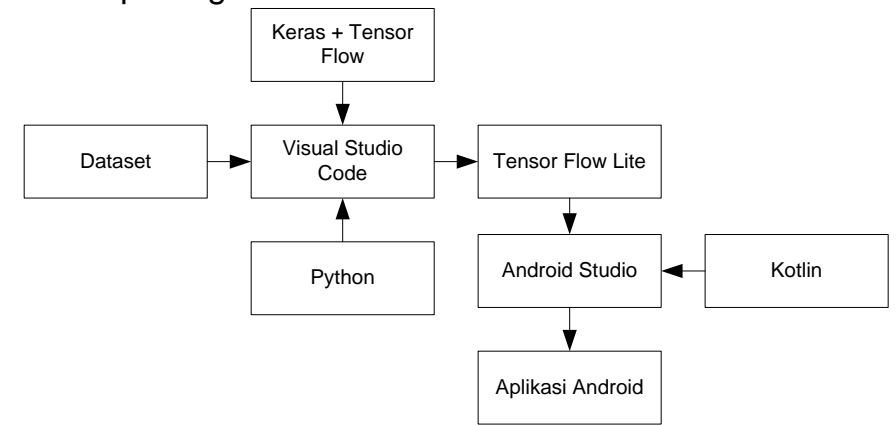

Gambar 1 Desain Arsitektur Sistem

Proses awal tahap desain artitektur sistem ini yaitu menyiapkan dataset, dan membuat kode sumber untuk aplikasi menggunakan CNN dan mengimport framework keras dan tensorflow pada aplikasi visual studio code disimpan dengan format .ipynb, sistem yang dibangun menggunakan model CNN ini menggunakan arsitektur mobileNetVI, kemudian metode transfer learning dengan mengambil file keras .h5 dimana sebelumnya sudah dilatih, setelah itu melakukan feature extraction pada file tersebut, dan sebagai tambahan untuk klasifikasi luaran pada aplikasi yang akan dibangun ditambah feature map.

c. Pengujian

Pada tahap terakhir yaitu pengujian, seluruh dataset pelatihan dilatih pada arsitektur jaringan CNN yang digunakan dengan epochs yang diuji yaitu nilai 100 . Kemudian dataset pengujian diekstrak dan dibandingkan hasilnya dengan data pengujian untuk melakukan prediksi pada klasifikasi jenis penyakit daun padi.

Setelah pengujian selesai maka hasil pelatihan dikonversi ke dalam format TensorFlow Lite dengan extention .tflite. Kemudian membangun program pada Android Studio dan memasukan file .tflite kedalam folder assets pada direktori project Android Studio tersebut. Setelah program dibuild menjadi file .apk, maka aplikasi Android klasifikasi tiga jenis penyakit daun padi tersebut pada smartphone Android. 


\section{Hasil dan Pembahasan}

\subsection{Hasil pelatihan dan pengujian}

Pelatihan dan pengujian pada Software Visual Studio Code berfungsi untuk melatih dataset dan memperoleh modelnya serta melakukan pengujian dari hasil pelatihan tersebut.

Pada penelitian ini proses pelatihan menggunakan 100 Epochs dan hasilnya dapat dilihat dibawah ini:

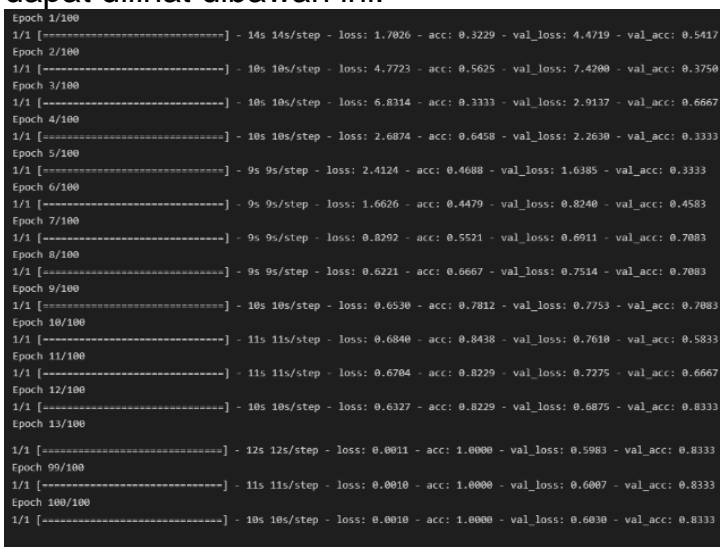

Gambar 2 Hasil Proses Epochs

Berdasarkan hasil pelatihan dengan 100 epochs dapat dilihat bahwa hasil pelatihan dan validasinya semakin meningkat mendekati nilai 1.0 seiring bertambahnya epochs. Pada nilai epochs 100 nilai akurasi pelatihan mencapai 1.0 dan nilai akurasi validasi mencapai 0.8333 . Dan nilai kesalahan pada saat proses pelatihan yaitu 0.0010 , sedangkan nilai validasi kesalahan yaitu sebesar 0.6030 . Sehingga nilai validasi kesalahan lebih tinggi dibandingkan nilai kesalahan proses pelatihan, hal ini akan terjadi overfitting.

Pada hasil pelatihan dan pengujian pada arsitektur mobilenetVI didapat hasil kurva akurasi dibawah ini:

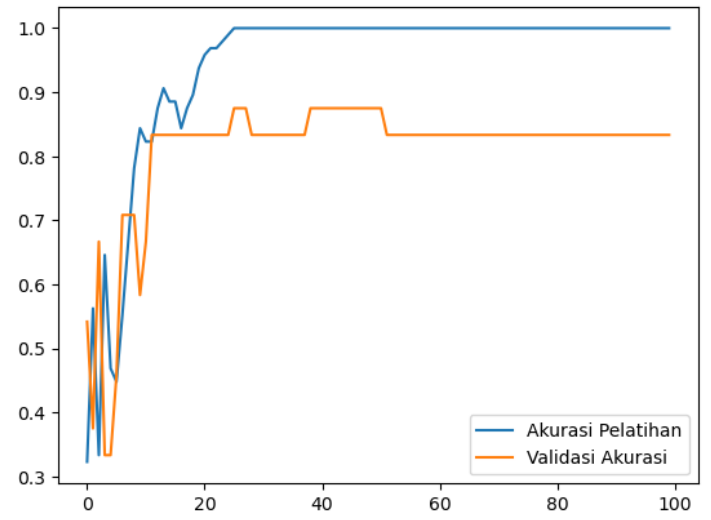

Gambar 3 Kurva akurasi hasil pelatihan

Dan kurva kesalahan selama proses pelatihan dapat dilihat pada gambar 4 dibawah ini:

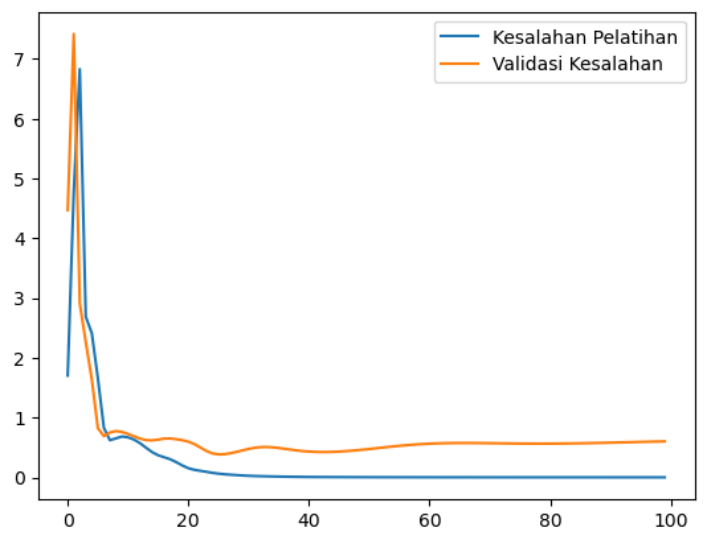

Gambar 4 Kurva tingkat kesalahan hasil pelatihan

\subsection{Hasil Validasi Confusion Matrix}

Hasil pelatihan confusion matrix yang digunakan untuk mengetahui tingkat keberhasilan dan kegagalan pada pengujian yang dilakukan. Berikut hasil confusion matrix:

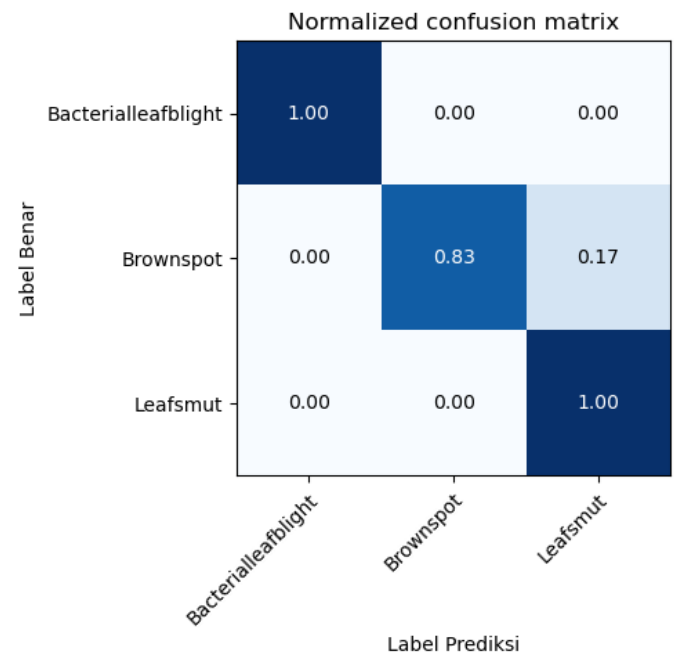

Gambar 5 Confusion Matrix Hasil Pengujian

Berdasarkan confusion matrix dari hasil pengujian tersebut dapat disimpulkan bahwa hasil prediksi berlabel benar dari jenis penyakit daun Bacterial leaf bligt memiliki nilai 1.0 hasil prediksi berlabel benar pada jenis penyakit Brown Spot bernilai 0.83 dan hasil prediksi berlabel benar pada jenis penyakit Leaf Smut yaitu dengan nilai 1.0. Dan terdapat 0.17 terjadi kesalahan prediksi yaitu pada jenis penyakit Brown Spot.

\subsection{Hasil Pengujian Pada Aplikasi Berbasis Android}

Aplikasi yang dibangun yaitu aplikasi berbasis android dengan menerapkan 
algoritma CNN dan arsitektur MobileNetV1 dapat dilihat pada gambar dibawah ini:

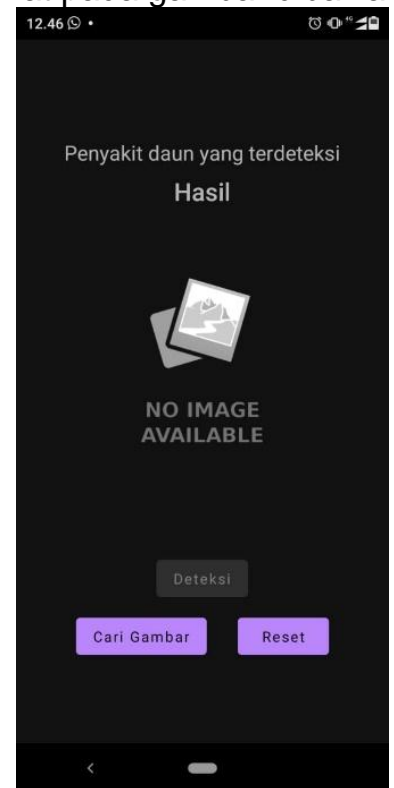

Gambar 6 Aplikasi Andorid Deteksi

Penyakit Daun Padi

Penggunaan aplikasi yang sudah dibangun ketika dijalankan, pertamakali akan muncul seperti gambar 6, klasifikasi gambar pertama dimasukan dengan menekan tombol cari gambar, ketika di pilih gambar penyakit daun padi maka akan muncul jenis penyakit daun padi, seperti gambar 7 dibawah ini

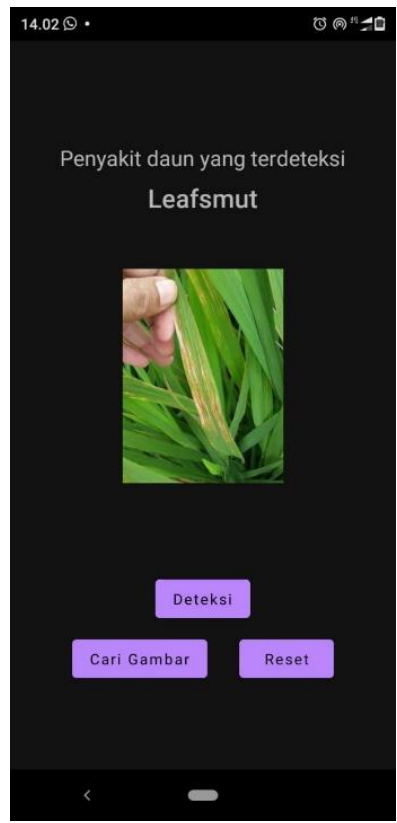

Gambar 7 Hasil Klasifikasi Penyakit Daun Padi

\section{Kesimpulan}

Klasifikasi gambar jenis penyakit daun padi menggunakan algoritma CNN dengan arsitektur MobileNetV1 dan Feature
Extraction memiliki akurasi yang baik sekali yaitu sebesar $92 \%$ namun dengan jumlah data cukup kecil dan penggunaan epochs yaitu 100, mengakibatkan nilai validasi kesalahan lebih tinggi dibandingkan nilai kesalahan pada proses pelatihan, sehingga akan terjadi overfitting.

Saran pada penelitian selanjutnya yaitu perlu adanya optimasi agar tidak terjadi overfitting dan aplikasi yang dibangun berbasis android perlu dikembangkan agar dapat mendeteksi secara realtime, sehingga pengguna aplikasi tidak perlu menekan tombol deteksi.

\section{Referensi}

Chawathe, S. S. (2020). Rice Disease Detection by Image Analysis. 2020 10th Annual Computing and Communication Workshop and Conference, CCWC 2020, 524-530. https://doi.org/10.1109/CCWC47524.2 020.9031140

Isbah, U., \& Iyan, R. Y. (2016). Analisis Peran Sektor Pertanian Dalam Perekonomian Dan Kesempatan Kerja Di Provinsi Riau. Jurnal Sosial Ekonomi Pembangunan, (19), 45-54.

Jani, K., \& Noor, A. H. (2018). Klasifikasi Penyakit Daun Padi Berdasarkan Hasil Ekstraksi Fitur GLCM Interval 4 Sudut. Jurnal Teknologi Informasi Dan Komunikasi (JTIK) STMIK ProVisi Semarang, 03(01), 1-6. Retrieved from

https://ejournal.poltektegal.ac.id/index. php/informatika/article/view/669/632

Minarni, \& Warman, I. (2017). Sistem Pakar Identifikasi Penyakit Tanaman Padi Menggunakan Case-Based Reasoning. Seminar Nasional Aplikasi Teknologi Informasi, (5 Agustus 2017 ISSN: $1907-5022), 28-32$.

Nuryanto, B. (2018). Pengendalian Penyakit Tanaman Padi Berwawasan Lingkungan Melalui Pengelolaan Komponen Epidemik. Jurnal Penelitian Dan Pengembangan Pertanian, 37(1), 1. https://doi.org/10.21082/jp3.v37n1.201 8.p1-8

Phadikar, S., \& Sil, J. (2008). Rice disease identification using pattern recognition techniques. Proceedings of 11th International Conference on Computer and Information Technology, ICCIT 2008, (Iccit), 420-423. https://doi.org/10.1109/ICCITECHN.20 
08.4803079

Phadikar, S., Sil, J., \& Das, A. K. (2013). Rice diseases classification using feature selection and rule generation techniques. Computers and Electronics in Agriculture, 90, 76-85. https://doi.org/10.1016/j.compag.2012. 11.001

Pothen, M. E., \& Pai, D. M. L. (2020). Detection of Rice Leaf Diseases Using Image Processing. Proceedings of the 4th International Conference on Computing Methodologies and Communication, ICCMC 2020, (Iccmc), 424-430. https://doi.org/10.1109/ICCMC48092. 2020.ICCMC-00080

Rahman, C. R., Arko, P. S., Ali, M. E., lqbal Khan, M. A., Apon, S. H., Nowrin, F., \& Wasif, A. (2020). Identification and recognition of rice diseases and pests using convolutional neural networks. Biosystems Engineering, 194(August 2019), 112-120. https://doi.org/10.1016/j.biosystemsen g.2020.03.020

Saputra, R. A., Suharyanto, Wasiyanti, S., Saefudin, D. F., Supriyatna, A., \& Wibowo, A. (2020). Rice Leaf Disease Image Classifications Using KNN Based on GLCM Feature Extraction. Journal of Physics: Conference Series, 1641(1). https://doi.org/10.1088/1742$6596 / 1641 / 1 / 012080$

Soleh, M. I. (2020). Penggunaan Pestisida Dalam Perspektif Produksi dan Keamanan Pangan. Retrieved from Kementrian Pertanian website: http://tanamanpangan.pertanian.go.id/ index.php/iptek/16

Yang, J. H., Liu, H. X., Zhu, G. M., Pan, Y. L., Xu, L. P., \& Guo, J. H. (2008). Diversity analysis of antagonists from rice-associated bacteria and their application in biocontrol of rice diseases. Journal of Applied Microbiology, 104(1), 91-104. https://doi.org/10.1111/j.1365-

2672.2007.03534.x 